\title{
The Education of Developing Responsibility Value*
}

\author{
Semra Kiranli Güngör ${ }^{1}$, Deniz Bostan Güzel ${ }^{2}$ \\ ${ }^{1}$ Assistant Prof. Dr., Faculty of Education, Eskişehir Osmangazi University, Eskişehir, Turkey \\ ${ }^{2}$ Pre-school Teacher, Ankara Directorate of National Education, Ankara, Turkey \\ Correspondence: Semra Kiranli Güngör, Assistant Prof Dr., Faculty of Education. Eskişehir Osmangazi University, \\ Meşelik Kampüsü, 26480 Eskişehir, Turkey.
}

Received: February 4, 2016

doi:10.11114/jets.v5i2.1361
Online Published: January 16, 2017

URL: http://dx.doi.org/10.11114/jets.v5i2.1361

\begin{abstract}
The aim of this research is to improve different responsibility value education activities in pre-school value education. In Turkey, there is a yearly programme in which value should be gained in pre-school value education, but it is lack of activities and how. This research was performed with the studies in a total of 26 students aged five and six, from the beginning of February to end of March in a disadvantaged socioeconomically level school selected to teach the value of responsibility for the academic year 2013-2014 in Eskisehir. At first, the students' parents were informed about the research. Different activities were done with the students to teach the responsibility value. This research, figured in accordance with the qualitative research processes. The content analysis method was used as the research analysis method to analyze the data and themes and subthemes. The drawings of responsibility, comments on the drawings, the notes taken during the class discussion, and comments after storytelling, the content analysis were done. The results of this study showed that the application of the value of responsibility to teaching is useful for both students and parents. Student development and student perceptions about responsibility have been evaluated. The idea that responsibility should be considered as a value should to be carried on for life, beginning from pre-school.
\end{abstract}

Keywords: the value education, pre-school, qualitative research, content analysis

\section{Introduction}

Pre-school education process is an initial period in which prior knowledge is learned to form many behaviours and the foundation for personality is created. Basic values defined as our personal characteristics in the next period of our lives needs to be improved with programmed and systematic activities in this period.

According to M.E.B. (2014), the purpose of education is to make students gain knowledge, skills, habits and attitudes which will help children to live in harmony with the society. Children begin to lay a foundation of values that will continue for life with the help of the observed patterns and social relations that begin to develop within the family in the first years. Early childhood has a critical importance not only in moral development but in all aspects of development.

\subsection{Pre-school}

Pre-school has a great importance for the formation of personality and for gaining essential knowledge, skills and habits as children start to recognize themselves and the external world in this period, in other words learning starts. Children need support from other people because they cannot develop these gains on their own. Education occurs because of this need. It is necessary to organize pre-school education for a healthy development according to the needs of this period (MEB, 2014).

Pre-school education in the glossary of Turkish Language Institute is defined as education implemented by families, institutions to help children's physical, emotional and social development considering their characteristics of development, individual differences and talents from their birth to the age of compulsory education (TDK, 2014).

\footnotetext{
*Very small part of this study was presented as an oral presentation and at page: 135 as a half page published just abstract in Turkish in abstract, at VI. International Congress of Educational Research, 5-8 Haziran 2014, Hacettepe University, Ankara, Turkey. This article was completely developed and reorganized and it is different from short oral presentation and half page published abstract.
} 
Pre-school is an educational process that covers, from a child's birth to the beginning of primary education period which complies with the individual characteristics of children at this age and their developmental level. Pre-school education that directs children's areas of development in the best way provides environment facilities in which there are rich stimulants. The quality of education in this period is extremely important in order to raise healthy individuals (Çetinkaya, 2010).

Ruffin (2009) tells that, one of the most challenging roles of care givers of small children is to help guide their behavior. This should be succeed by showing respect, kindness, and persistence when interacting with young children. Normal young children are curious, active and impulsive, and recognizes that the main goals of positive management are to assist children to develop responsibility, to learn and develop skills to control themselves own behavior. In mid-four to sixes-major tasks are; learning an identity. In these ages, they show lots of energy, wiggling, and giggling; loves to talk about self; can do many things and loves to show them off; has many new fears; still tells tales; may try out taking things that belong to others; tattles and is a poor loser; shows interest in numbers and letters; begins to play cooperatively with others, but disagreements can easily occur. Care giver should: Give affection, clear directions, and expectations; encourage the child to try new things; provide a variety of activities that allow the child to learn by doing; let the child participate in planning activities and doing small, helpful chores; provide opportunities to show off skills.

\subsection{Value Concept}

The general and specific objectives of the education services are to adapt children and young people to social life in a healthy way. Teaching general, universal, proven and settled values in compliance culture forms the general education. Acculturation covers knowledge, skills and moral elements that needs to know and learn and that provide the society with well-being. If this harmony does not happen literally, conflict and communication difficulties occur between humans (Varış, 1998).

Bloom (1948) developed classifications of intellectual behavior and learning in order to identify and measure progressively sophisticated learning. Three domains of learning are; cognitive domain defining knowledge classification, psychomotor domain and affective domain. defining behaviors that correspond to attitudes and values. Affective outcomes tend to be the hardest to articulate initially and often appear difficult to assess at first glance. However, cognitive outcomes often represent the outcomes most closely related to deeper thinking and life-long learning, as well as the outcomes we value most. In receiving process, students become aware of an attitude, behavior, or value. In responding process, students exhibit a reaction or change as a result of exposure to an attitude, behavior, or value. In valuing process, students recognize value and display this through involvement or commitment. In organising process, students determine a new value or behavior as important or a priority. In characterizing process, students integrate consistent behavior as a naturalized value in spite of discomfort or cost. The value is recognized as a part of the person's character.

Children initially learn the values from their families, the media, their peers, play groups, their caregivers, the environment they live in and other institutions in very early period of their lives. Strong evidences that reveal children develop the moral sense in the first two years of their lives have been put forward by research and this period is closely related to children's social and emotional development (Buzelli, 1992). Values come to the forefront in education when children start school. The duty of the school community is to help children to recognize and develop the values in the society and apply them to their lives (Halstead and Taylor, 2000). Today, value education is discussed in almost all developed countries (Tozlu, 1992).

Our education system and the schools as implementers in this process have important duties to help children gain. Values which are a key aspect of the education system, first people can live in harmony with others in society, second sustain their lives in a better way, third the basic knowledge and skills to make real first and second, are given to children at primary education level. Even if schools do not put "value education" course in their education programs, they teach the values with the hidden curriculum because the structures such as atmosphere of schools, teachers and discipline approach and expectations teach values or contribute to students' growth (Akbaş, 2004). The value of education in which human beings are largely shaped is important for children to create a balanced personality later in their lives. Therefore, providing certain values with individuals starting from pre-school is one of the most important tasks of education system. Value education is one of the leading education topics of which popularity is growing. Many countries have started to address and give attention to this issue in recent years (Pring, 2010). In fact, value education is a common name today for moral education and character education that we faced in the past curriculum as a spiritualization process. Value education as a simple statement is a clear attempt to teach values. "A matter of value education in Turkey" which is quite new subject to be developed. 


\subsection{Responsibility Concept}

Responsibility has been defined in different ways in the literature. Some of these definitions are: people assume the consequences of any event or behavior within its own limit of authority (TDK, 2014); assuming the responsibility for his own and moral subject's actions and an individual's situation who can achieve the things with complete awareness, freedom, taking the responsibility of the results and developments that are because of his psychological formation, assessing them as a conscience duty (Cevizci, 1997); according to Yavuzer (1998) responsibility can be defined as children's fulfilment of their duties according to their age, gender and level of development. Responsibility is a unique human emotion. People are socially responsible for their behaviors towards members of community in society (Pehlivan, 2003). Responsible person is respectful to himself/herself and others. S/he fulfils his/her own duties. She/he conducts his/her tasks by himself/herself and s/he does not want to bother others. S/he holds just himself/herself responsible for his/her feelings, thoughts and behaviors. His/her expectations from life are proportional to what s/he gives to life. S/he does not want to get what s/he does not deserve. S/he is a hardworking and good person and a good parent (Altınköprü, 1999).

Can (2008) has stated that responsibility and respect are the most important values in research on values. Yigittir (2010)'s research results have showed that parents of elementary students wish that responsibility value can be acquired in schools. According to Tepecik (2008)'s research results, almost all of the teachers have stated that responsibility value should be learned in family first, in contrast, they have also pointed out that the values learned in school are not repeated at home or outside the school, and that the source of the problems they face in society is because of the insufficiency or absence of the sense of responsibility in family. Aslan (2007) has stated in his research that responsibility value is gained at the lowest level according to the teacher and the reason for this situation is that parents of primary school students are disinterested in bringing values. Families have important roles in children' gaining the responsibility value. Families can be taught in primary schools about the importance of value education, families' roles when making children gain values, supporting the values at home in the context of school-family cooperation.

In Yaşar \& Çengelci's research (2009), social studies course has an important role in value education. However, school, teacher, family and society are not enough to provide values education with better process. In Tay , Durmaz \& Şanal's research (2013) in which 4th, 5th, 6th and 7th grade students stated their opinions about values education, it can be seen that responsibility value is one of the values that students did not point out in their answers when they were asked: "Which values should be given in social studies?". In Yeşil's research (2003) concerning in which level responsibility value takes place at students' behavior, the majority of students could not show sufficient behaviors related to responsibility. In Baydar's research (2009) which is related to level of gained values of fifth grade students in Social Studies program, it was determined that according to the results achieved by moral dilemmas forms used for each value, student's gaining level of responsibility values is at traditional level, in other words at a low level. Atabey (2016)'s research based on "Social Values Education Program" developed by the researcher was used to show the effect of the social values education program on the social values of the children who continue their education in kindergarten. The "Social Values Education Program" is based on illustrated children's books. Social Values Education Program "has proved that children are effective in the acquisition of social values and this effect is permanent.

One of the most important windows opened from the imaginary world of the child to the real world is illustrated story books. The characters in the illustrated storybooks have the opportunity to move their behaviour into the real world by taking a child's sample. By using picture books children can adopt values by taking the behaviour of their characters. Dirican \& Dağlioğlu's research (2014) was based on basic humanistic values included in the illustrated story books written by Turkish authors for 3-6 years old children. The content analysis method was used for research purposes. The sampling consisted of 135 illustrated story books selected by using purposive sampling procedure. 20 values in total were found, responsibility was the seventeenth value. Gönen, Katrancı, Uygun, M. and Uçuş's research result (2011) was similar to Dirican \& Dağlığlu's research results (2014). Gönen et al.'s research result (2011) has shown that the least mentioned values in children's book were patriotism and responsibility.

Geisel (1940's book, Horton Hatches the Egg, by Dr. Suess which is a pseudonym of Geisel, fantastic fiction book is for 0-5 year's kindergarten children. This illustrated book was very popular. Even children learn responsibility with "Teacher's Egg-Sitting Game" Dr. Suess was a writer, an animator, a book publisher and a cartoonist. He was very popular, important teacher of literature for children. His book teaches children what responsibility and irresponsibility are. A short summary of the book is as following: 


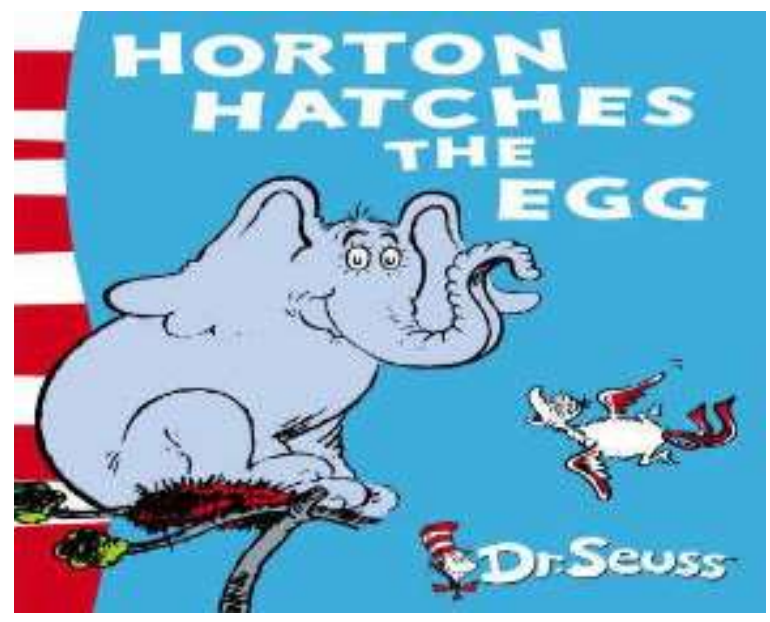

Picture 1. Horton hatches the egg

Mayzie the bird is tired of sitting on her egg. She wants to take a vacation. Horton the elephant comes along and Mayzie asks him to sit on her egg. At first he doesn't want to, but eventually he concedes and says he will. Mayzie flies away. Horton goes through a lot of experiences while is sitting on the egg, but never leaves the egg because he made a promise. One day strangers come by and want to put Horton and his egg in the circus. Eventually, after an extended period of time Mayzie comes back and sees Horton still on her egg. She wants her egg back because it the egg is starting to hatch. Horton is upset. He put in all the work to help the egg and does not want to give it back to Mayzie. To everyone's surprise, when the egg hatches it is an elephant bird!
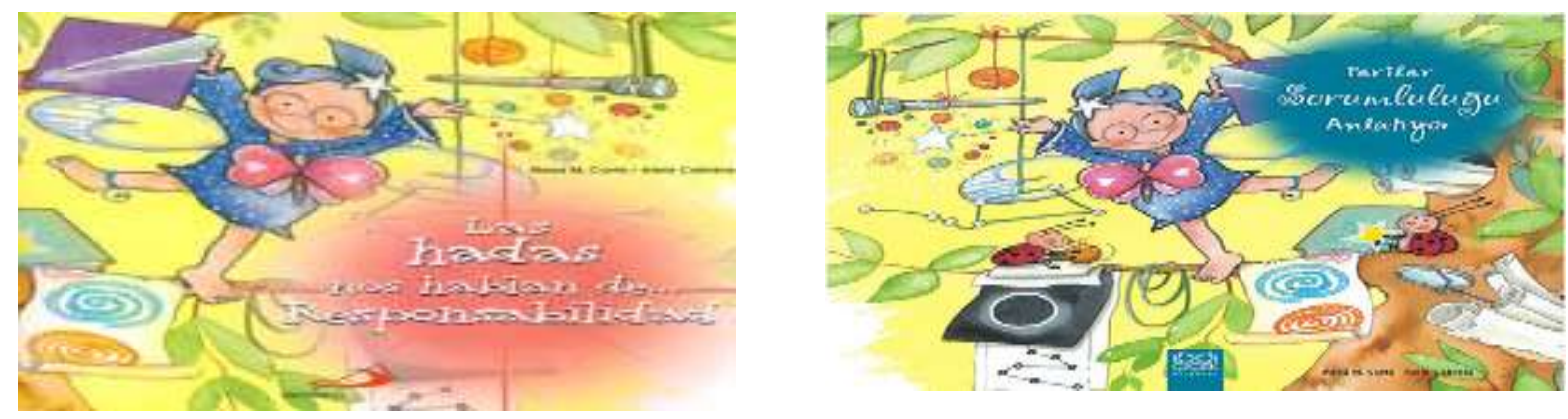

Picture 2 and 3

Cabrera and Curto's illustrated children's book (2011) "fairies tell us about responsibility" originally "las hadas nos hablen de responsibilidad" in Spanish, was translated in Turkish by Özyurt (2014). A short summary of the book is as following:

The protagonist of this story, the fairy Cascabel, assumes that she is a dreamer and invents a good excuse not to worry the rest of the fairies. Learn the value of responsibility and discover the magical world of fairies and nature. These stories will allow children and adults to discover different attitudes and values that are very important for everyday life. There are also didactic comments and explanations.

In this context, it would be useful to prepare the foundations of responsibility values with research in pre-school and to do more research in this field considering the majority of the studies on responsibility values are at primary education level.

\subsection{The Purpose of the Research}

The aim of this research is to improve different responsibility value education activities in pre-school value education. In Turkey, there is a yearly programme in which value should be gained in pre-school value education, but it is lack of activities and how. On the other hand, pre-school education is the first step of education life of any child, in this period developing value education is important for young children. This research was carried out to present qualitatively the results of responsibility value education which is given with four step different improvement activities and planned in the scope of values education in schools and also to contribute to the responsibility value education. 


\section{Method}

\subsection{The Method of the Research}

The research has been carried out with a qualitative research method. Qualitative research is aimed at gaining a deep understanding of a specific organization or event, rather than surface description of a large sample of a population. It aims to provide an explicit rendering of the structure, order, and broad patterns found among a group of participants. It is also called ethnomethodology or field research. It generates data about human groups in social settings (https://web.csulb.edu/ msaintg/ppa696/696quali.htm.). Qualitative research methods originated in the social and behavioral sciences: sociology, anthropology, psychology and education. Qualitative researchers stress the socially constructed nature of reality, the intimate relationship between the researcher and what is studied, and the situational constraints that shape inquiry. Such researchers emphasize the value-laden nature of inquiry. They seek answers to questions that stress how social experience is created and given meaning Qualitative research is especially effective in obtaining culturally specific information about values, behaviors, beliefs, opinions, emotions, and relationships of individuals and the social contexts of particular populations (http://libguides.usc.edu/writingguide/qualitative) .

At each stage of the research, developing methods and approaches, making changes in the design of the research Constitute the essence of the research. One characteristic of qualitative research is the explorer they are. Exploratory features, less studied topics. It is very useful and useful in lighting (Neuman, 2012: 228). Denzin and Lincoln (2005) says that qualitative researchers study things in their natural settings, attempting to make sense of or interpret phenomena in terms of the meanings people bring to them." Qualitative research questions are the why and wherefores rather than asking "how often" something occur and how widespread it is. In qualitative research we ask things like: who is doing or involved in something, how is it done, for what kind of reasons? What is done, what kind of steps are followed in what kind of order, what kind of strategies are used, what are the consequences of doing or not doing something, why is this like this, wherefore is it done and why? Qualitative research methodology, design and implementation of research give researchers flexibility.

Analyses were done and presented by content analysis method. Content analysis is a systematic analysis of written and oral materials. The basic process in content analysis is to bring together, edit, comment on similar data under specific themes (Yıldırım \& Şimşek, 2006) Content analysis has preliminary analysis, coding, categorization, inferencing stages, as well as an interpretive value. Category creation is not a simple sequence, but thinking, evaluation, meaning lighting, evidence creation (Bilgin, 2006). The investigator can compare conceptual (coding, theme) categorizations with other coding derived from verbal. The researcher constructs the categories from his own data, revealing the similarities and differences in the categories he creates with the concepts (Glaser \& Strauss, 1967).

\subsection{The Participants of the Research}

The research was carried out by the studies that were achieved with 26 students aged five and six, in two classes, two teachers and students' parents throughout February-March months in Eskişehir in a socio-economic disadvantaged school selected for 2013-2014 academic year to give responsibility value education. Their parents were nearly poor, many of their mothers were housewives, and their fathers were working for long hours. Some of the fathers were unemployed in some periods.

26 students aged five and six were the participants of responsibility value education planned to be given with different studies in the context of values education. Five of the students were four years old and the others were five years old. The teachers in the classrooms where this study was done were also participants of this research. Both teachers had got degrees of pre-school education; both were women and both had about 10 years of experience in teaching.

\subsection{Gathering Data}

Student's parents were notified of teaching value of responsibility which was going to be done at home and at the school. Contribution of the student's parents as well as the students themselves was necessary for this study, and this necessity was conveyed to them.

Step 1: Firstly, in this study, some practices were done for students to gain value of responsibility. The question of 'What is responsibility' was asked to the students and their answers were noted.

Step 2: Secondly, a study of gaining and learning responsibilities for students was done with the participation of students' parents. Within this study, students were asked to decorate eggs with any left-over materials together with their parents in order to give responsibility to them (their parents). Students prepared this study at home with their parents. At the end of this study, each student was asked to bring his egg to the class every day for the following two weeks without forgetting and breaking them. At the end of this duration, students were rewarded with responsibility medals which were made of left over materials. 
Step 3: Thirdly, a story book about responsibility was read. After the story, question-answer method was used to create an ambiance for students to discuss about the topic and characters in the story. These answers were noted down.

Step 4: Fourthly, students were asked to draw picture of responsibility. These drawings were asked to each student in order to express what they had intended, and their responses were written down. With display of these drawings and participation of student's parents, it was completed

\subsection{Analysis of Data}

As a research method, in the research, experts of qualitative analysis and management of education fields worked together with experts of pre-school field, but there were moments of getting help from guidance and psychologist consultants and art teachers also when they were needed, moreover they worked in the evaluation of data as a group. Reason for this was to strengthen validity and reliability.

In the research, context analysis was used as an analyzing method. Responsibility drawings, drawings made by students in the class, textual expressions taken from the display of drawings made by students, notes taken from the discussions related to the responsibility of the class were all themes and subthemes of the context analysis. Context analysis helps to show and define hidden facts. The basic functions of context analysis are to collect, to arrange, to interpret similar data under the specific titles (Yıldırım \& Şimşek 2006). Hermeneutic paradigm was used to analyze.

Coding in qualitative research means to assign a word or a phrase that summarizes a section of data. It can capture the essence of what is in the section or it can be an evocative attribute. Coding has become a popular method with the spread of Grounded Theory methodology. It is however also used as a method to structure and organize data outside the Grounded Theory framework ( Yıldırım \& Şimşek 2006).

Reliability of the context analysis needs coding the same text in the same way by the different coders or coding the same text in the different times in the same way by the same coders. Validity of the context analysis is related to the accordance of the aims and tools. In the research, according to the participants that respond similarly or differently in the same work, one coding operation was made. Responses of participants in each work were saved in the tables separately. For examining basic features of collected data introductory analysis was used. In the process of coding data, codes can be changed, developed again and again. In this, any statistical transactions were not applied. According to the unified vision, last shape was given to the coding key. The coding of the researchers was compared, the reliability of the research was calculated as $90 \%$ by means of using the agreement percentage formula of (disagreement + agreement *100) Miles \& Huberman (1994). In the presentation of data, themes and subthemes were formed. But there was no need for frequency and percentages. Frequency means very small numbers and taking percentages expresses extensive meaning. On the other hand, data are important for the qualitative research, numerical measurement is not so important.

\section{Findings}

\subsection{Discussion about What Responsibility Is}

Discussion about what responsibility is analyzed and classified themes and subthemes in content analysis, so in Table 1 below, presented the analysis of it,

Table1. Context Analysis of the discussion "What is responsibility?" made in the class

\begin{tabular}{ll}
\hline Themes & Subthemes \\
\hline A. Self-responsibilities & A1.Plants and Animals \\
A1.1. Taking care of flowers and trees. & A1.2 . Feeding birds, dogs, cats and fish \\
& A2. Personal \\
A2.1 Doing homework \\
A2.2 Tidying up the room and the bed \\
A2.3 Picking up the toys \\
A2.4 Sitting on the back seat of the car \\
A2.5 Wearing on his/her \\
A3. Family \\
A 3.1 Helping mother and father \\
A 3.2. Looking after brother or sister \\
A4. Teacher \\
A 4.1 Obeying the rules of teacher \\
A 5. Neighbours \\
A5.1 Visiting and inviting neighbours \\
B1. Cooking food \\
B2. Cleaning the house \\
B3 Taking care of children \\
C1. Going to work \\
C2 Earning money
\end{tabular}


By discussing "What is responsibility?" it was tried to learn what children understand from responsibility. In the table, main unit 1 came out related to the context analysis. These are self-responsibilities, responsibilities of mother, and responsibilities of father. It's very important to have a high level of self-responsibility in terms of individual responsibility improvements. General answers to responsibilities show a socio-economic disadvantaged school district.

\subsection{Responsibility Coming from Egg Practice}

Students were asked to decorate eggs with any left-over materials together with their parents in order to give responsibility to them (their parents). Students prepared this study at home with their parents. At the end of this study, each student was asked to bring his egg to the class every day for the following two weeks without forgetting and breaking them

In the second and the third day, two students in total forgot to bring their eggs. Later they did not forget to bring their eggs. In the fourth, the seventh and the eighth day, three students in total broke their eggs, but they attended to an activity with their new eggs. Later they did not break their eggs. Students did not forget their responsibility related to the activity in high ratio.

In this activity "Responsibility brought by egg", it was asked to parents to decorate the eggs with their children, with the aim of giving responsibility. Children got prepared for this activity with their parents until the scheduled date. It was asked to children to bring their decorated eggs to school and it was said to apply this activity for two weeks, except the weekend. After this process, responsibility medals made of leftover materials were given to students. In the picture 1-2-3 -4 samples of painted eggs are seen, made by students in the activity.

Stranix and Fleishman's study (1979) was named, The "Eggs-act" Way to Teach Responsibility. As a lesson about responsibility and parenting, junior high school students were given eggs as their "children" and told to care for them for two weeks. Students also participated in various small group projects studying the characteristics and needs of three year olds.
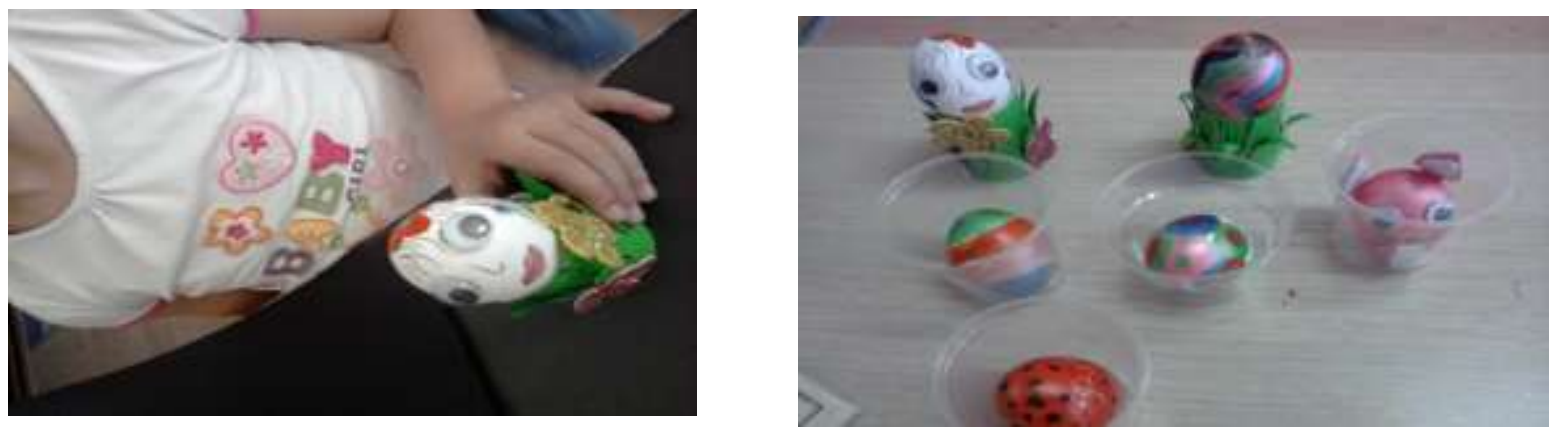

Picture 4-5-6-7. Some students' differently decorated eggs from an activity of responsibility brought by egg
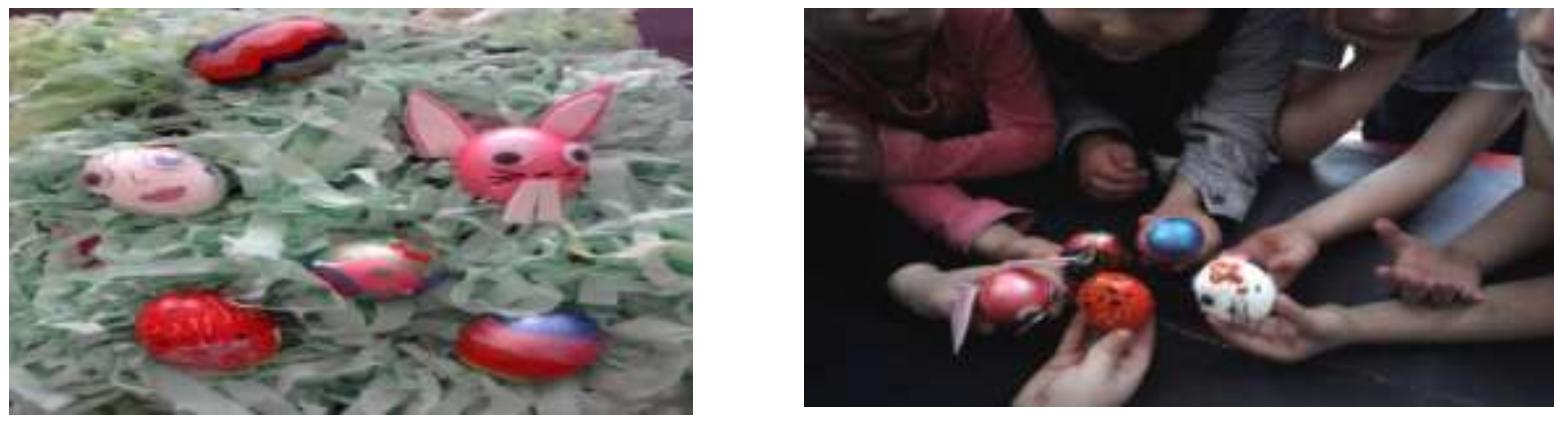

3.3 The Story of the Penguins' Responsibility

The story of the Penguins' responsibility was read to students. Then students were asked about their opinions about the responsibility of penguin. In the class, students have discussed this topic, feedbacks were noted down. In Picture 8, children are at the reading activity. 


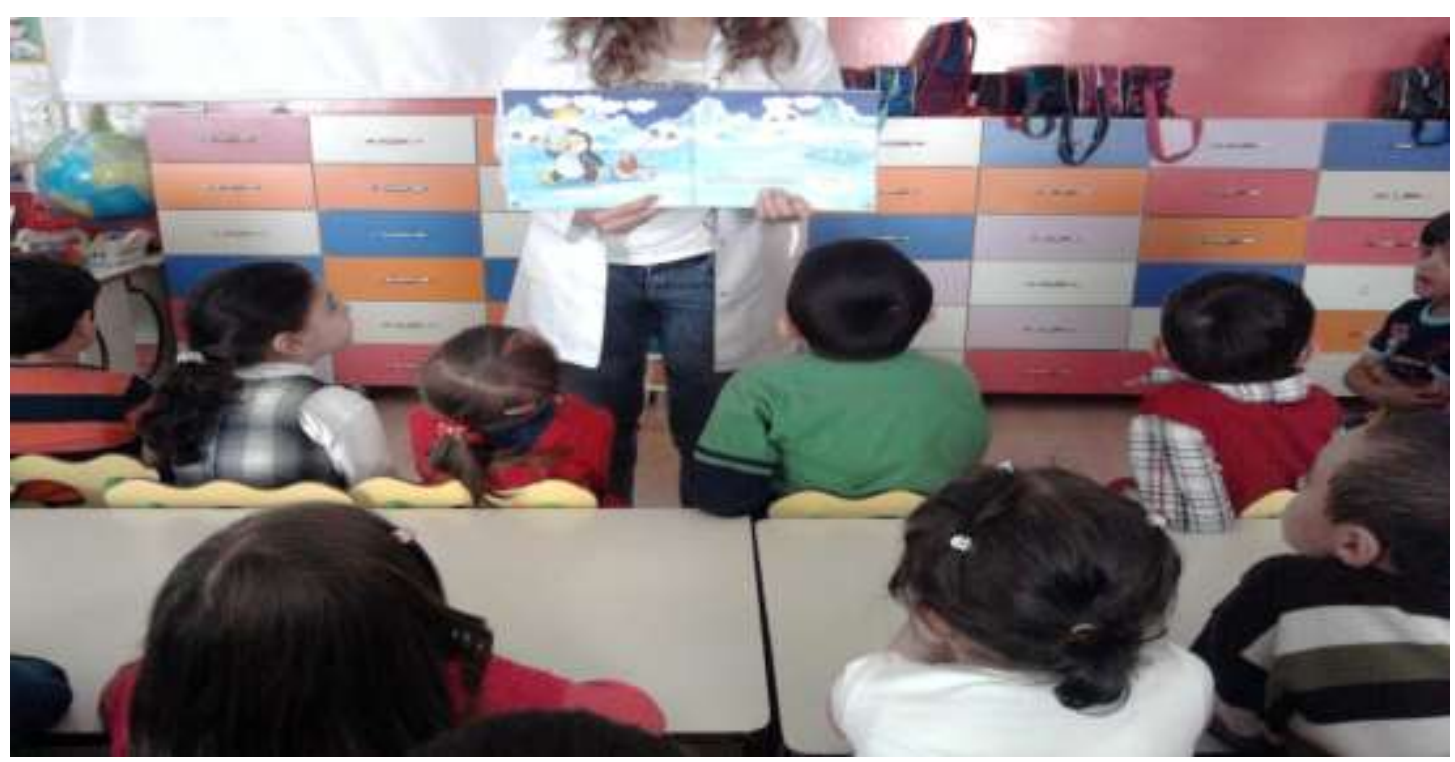

Picture 8. Telling the children the story "Responsibility"

In picture, a course in which responsibility story book is explained to students is seen while they are listening and following the story book.

These responsibilities are penguin's responsibility, fathers' responsibility, outcomes of irresponsibility, compensation of irresponsibility. There are four subtopics related to the most dominant main topic among the other main topics which is compensation of irresponsibility and in these four subthemes children are provided with very important learning terms of being constructive.

In table 2 main themes and subthemes came out from the content analysis of the story about responsibility.

Table 2. The content analysis of the story concerning responsibility topic

\begin{tabular}{ll}
\hline \multicolumn{1}{c}{ Themes } & \multicolumn{1}{c}{ Subthemes } \\
\hline A. Penguins' responsibility & A.1 Fishing \\
& A.2 Label \\
& A.3 Being careful \\
B. Fathers' responsibility & B.1 Helping mother \\
& B.2 Fishing \\
& B.3 Cleaning the fish \\
C. Outcomes of Irresponsibility & C.1 Forgetting duty \\
& C.2. Harming somebody \\
D. Compensation of irresponsibility & D.1 Apologizing \\
& D.2 Admitting a quilt \\
& D.3 Regretting \\
& D.4 Feeling sorry \\
\hline
\end{tabular}

\subsection{Drawing Picture of Responsibility}

At the end, students were asked to draw and colour a painting related to responsibility with crayon. Students finished drawing, after that each student explained his/her own drawing and for these explanations were noted down. After students' explanations, the content analysis of drawings was done. During the analysis, the help of the researchers, the art teacher and the counsellors was asked for. Main themes and subthemes which are found were similar to table 1 . These main topics are self-responsibilities, and parents' responsibilities. Among these responsibilities, one of the biggest ones is self-responsibilities. After children drew, every child told about their drawing one by one. One researcher asked the children what s/he drew, and other researcher took notes at that moment. After that procedure completed, researchers evaluated drawings together. 


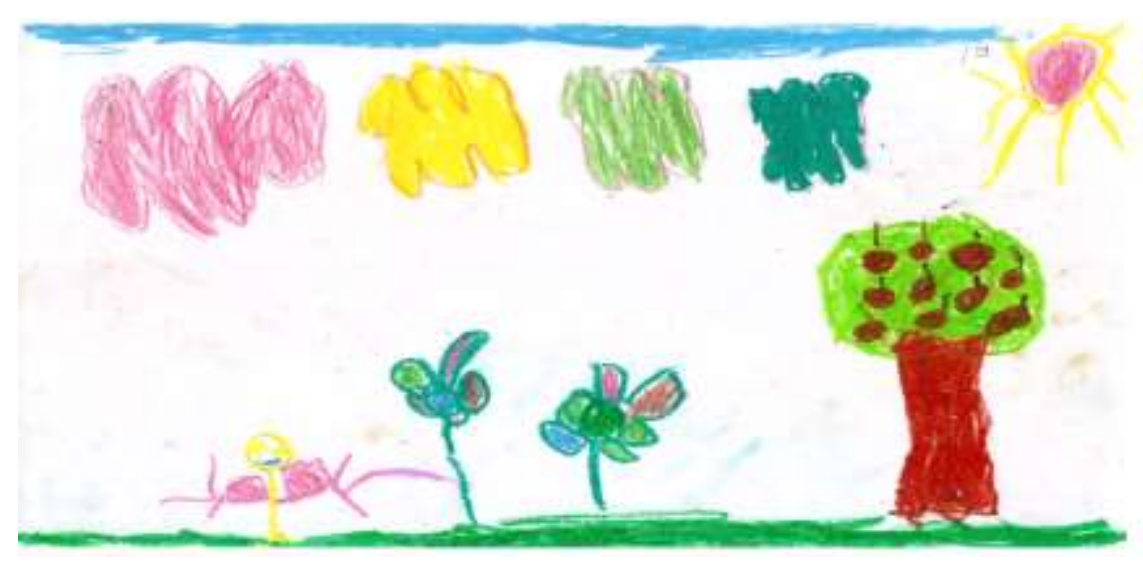

Picture 9. An example of drawing for taking care of trees and watering flowers

It is an example of one of the child's responsibility understanding. He draws himself taking care of the tree, watering flowers. He is a yellow boy with pink hands.

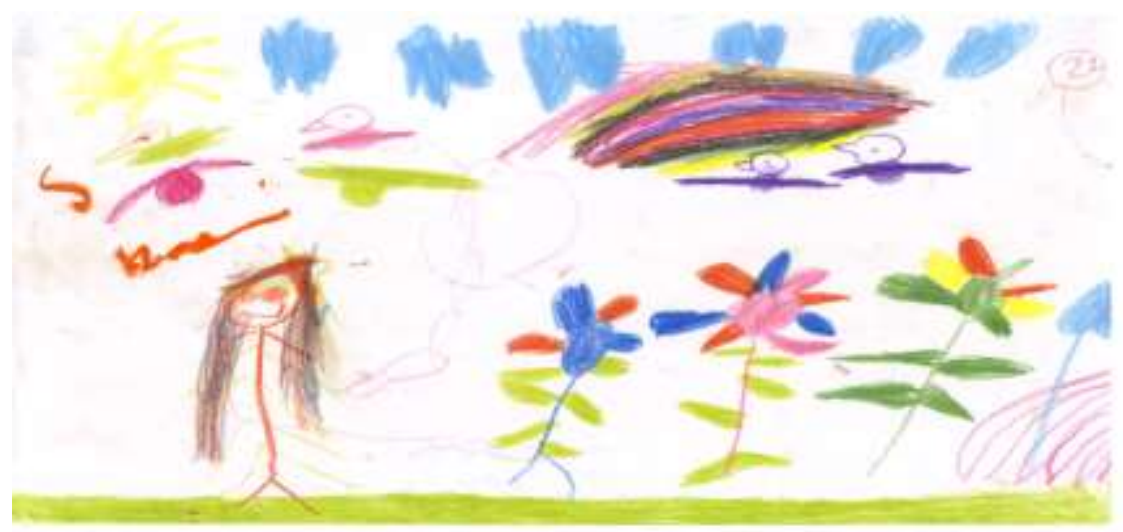

Picture 10. An example picture for feeding birds and watering trees

It is an example of one of the child's responsibility understanding. She draws herself feeding birds, watering flowers. She is red and very long black haired.

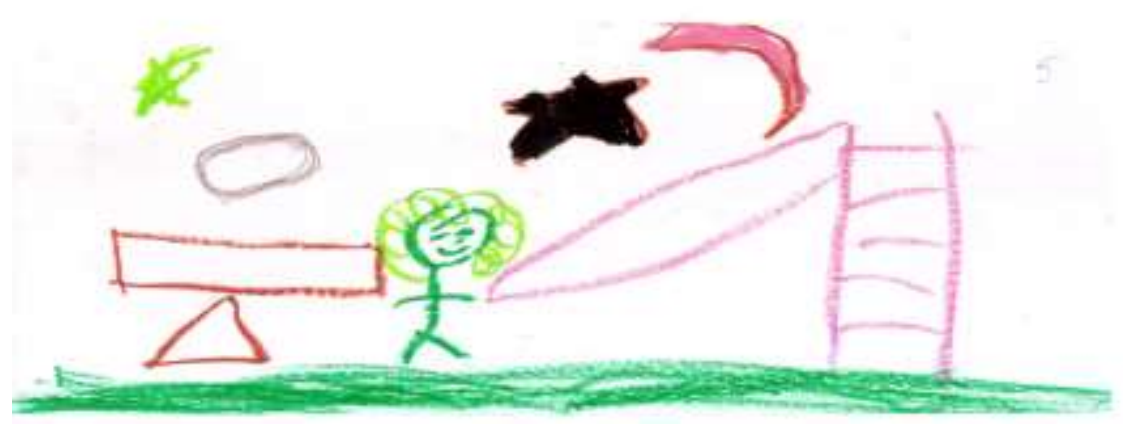

Picture 11. An example of drawing for doing homework

It is an example of one of the female students' doing homework. After she drew, she told she learned geometric shapes. There is one triangle shape, one rectangular, one ellipse shape. She is green. She is in the playground. There is a green star, black star and red moon, pink ladder. It is very interesting. It shows her imagination. 


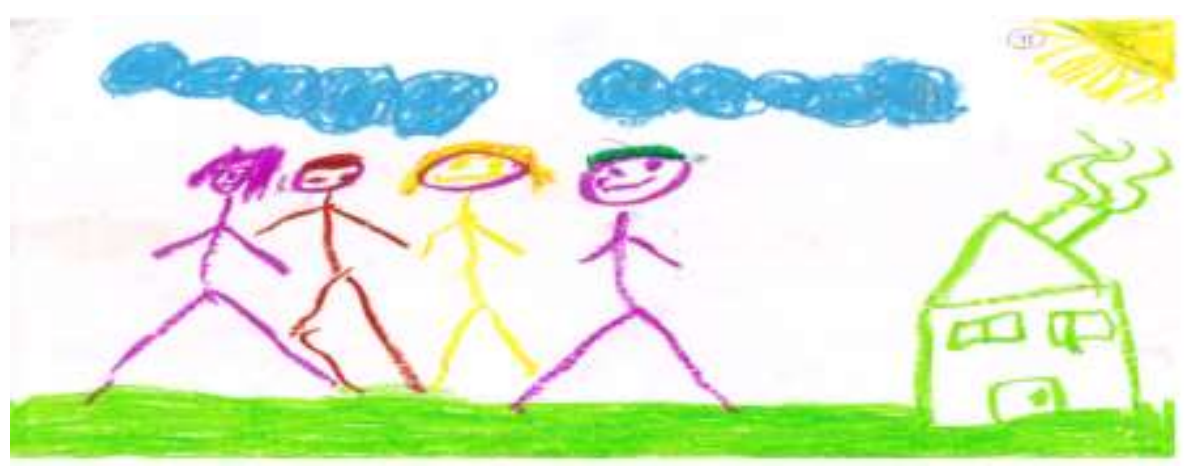

Picture 12. An example of drawing for going to school with friends

It is an example for the boy student's going to school with his friends. He is purple boy with his green hat. It is shining. They are happy for being together and going to school.

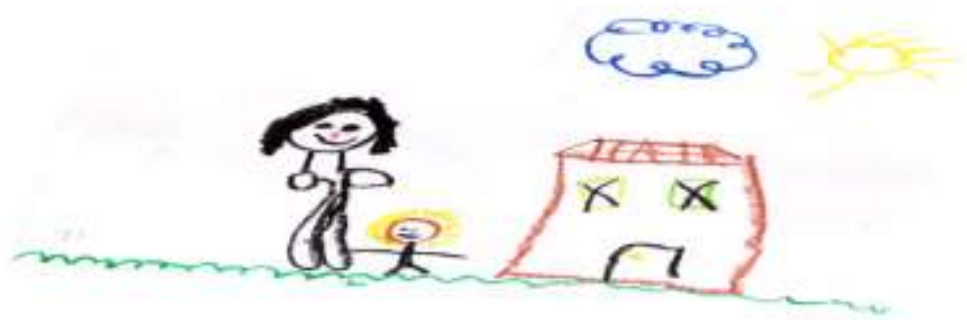

Picture 13. An example picture for taking care of her younger brother

It is an example for the male students' taking care of his younger sister. He is black with a long black hair. She is very happy. They are smiling. They are near their home.

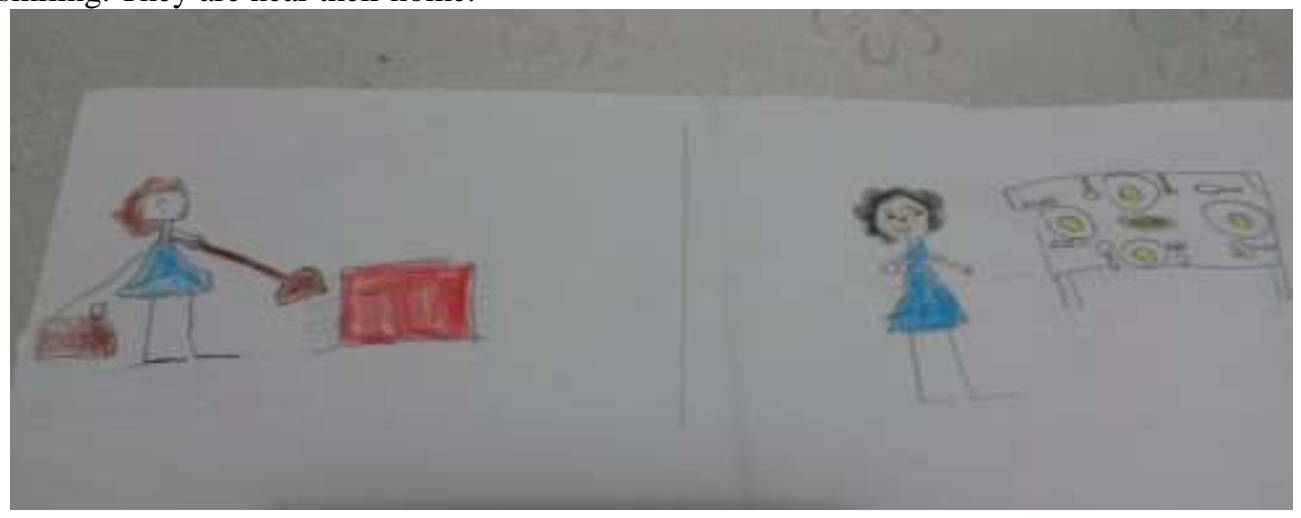

Picture 14. An example drawing for helping mother

She is blue dressed, her mother is blue dressed. Meal table is ready for four people. Plates of children are small; father and mother's plates are big. Spoons and forks are ready near the plates.

\section{Discussion and Conclusion}

In scope of education values, responsibility value is analyzed in four different steps that are discussion about what responsibility is, responsibility coming from egg practice, the story of the Penguins' responsibility and drawing picture of responsibility.

It's seen that the studies conducted are highly important for children especially in gaining individual responsibilities. Moreover, it's seen that students achieved important and positive gains in terms of parents, occupation responsibilities, responsibilities at home, and in the school, and in society, results of irresponsibility and compensation of irresponsibility.

The overall result of study is that when the pre-school students are taught responsibility education it's observed that the students comprehend, consolidate and put the notion into practice. These kinds of practices are beneficial and successful for pre-school students in acquiring the responsibility notion. 
Responsibility value of students' related to self-responsibilities, there are plants, animals, parents, brothers/sisters, teachers, friends, neighbours. They have defined their individual responsibilities. During the egg carrying activity, it can be understood that the majority get responsibility. They also accomplished the parents' responsibilities. However, in children's responsibility observed, some effects occurred in studies conducted in schools with disadvantages in terms of socio-economic level. In evaluations of both first and fourth steps of the research, students define self and parents' responsibilities according to this criterion. Generally responsibilities of fathers are defined as working a lot and earning money while mother does the housework and taking care of children. In this case, only father is working and earning money. Mother takes all the other responsibilities.

The study about child's helping mother conducted by Ay \& Dal (2014) listed the responsibilities as doing homework, studying, preparing school materials, going to the school and returning home in time, obeying the school and classroom rules, accomplishing the given task in time and using the school objects carefully. Deveci \& Selanik Ay (2009) as results of the study determines that value education should be included into planned education program. Also, in Gömleksiz' \& Cüro's research (2011), seventh grade students showed that they mostly pay attention to personal hygiene (related to responsibility). Ay \& Dal in their study (2014) stated the list of personal hygiene, the attention to self-care, sleeping, waking up in time and fulfilment of the responsibilities required by occupation. In this context, it can be listed as a result of Such \& Walker's deep discussion (2004) about responsibility perception notion study. It's seen that children perceive the responsibility at home as a normal and inevitable part of their daily lives. The scarcity of subthemes of home responsibility can be interpreted as the insufficiency of responsibilities given to children at home.

As a result of knowledge obtained from literature "responsibility value improvement in pre-school education in Turkey", it can be suggested that the 'responsibility notion' themed studies are not sufficient and these studies should be improved in schools. Considering the lack of responsibility notion, in extent of pre-school values of education it will be beneficial to increase the studies. This research should be conducted in different schools because the comprehension and perception of responsibility criterion of students can be different. While preparing the values of education program and planning, the state directorate of national education and schools should make an effort to include more detailed improving value education activities instead of just written which value should be improved. It will be beneficial for this field to increase the number of different qualitative studies in terms of value education. In order to explain the importance of responsibility, informative lectures, seminars, workshop workings can be arranged to families in the scope of responsibilities. Social responsibility projects that can provide participation of family-school-teacher-student can be developed.

\section{References}

Akbaş, O. (2004). Evaluation of the degree of reaching of affective goals at the elementary level in Turkish national education system. (Unpublished Doctorate Thesis), Gazi University, Institute of Educational Sciences, Ankara, Turkey.

Altınköprü, T. (1999). How Is The Child's Success Achieved. İstanbul. Hayat Publisher.

Aslan, R. (2007). According to teacher's views levels of gaining of Primary Education Students' Basic Knowledge, Ability and Levels of Developing Levels..(Yayınlanmamış yüksek lisans tezi), Anadolu Üniversitesi, Eskişehir, Turkey.

Atabey, D. (2014). A study into the development of scala for preschool social values acquisition and effect of the program of social values education on the social values acquisition of children attending to a kindergarten. (Unpublished Doctorate Thesis) .Ankara: Gazi University, Institute of Educational Sciences

Ay, T. S., \& Dal, S. (2014). Primary School Students' Perceptions of Responsibility Value with Their Written Expression Products. Dicle University Journal of Ziya Gökalp Education Faculty, 22, 78-93.

Baydar, P. (2009). Evaluation Levels of the Values Determined in the Fifth Grade Social Studies Program in Elementary School and Evaluation of the Problems in this Process. (Unpublished Master Thesis), Çukurova Üniversitesi, Adana, Turkey.

Bilgin, N. (2006). Content Analysis in Social Sciences.Techniques and case studies. Ankara:Siyasal Publishing.

Buzzelli, C. A. (1992). Research in Review Young Children's Moral Understanding: Learning about Right and Wrong. Young Children, 47(6), 47-53.

Cabrera, A., \& Curto, R. M. (2011). Las Hadas Nos Hablan De Responsabilidad. Argentina: San Pablo

Can, Ö. (2008). The Opinions of fourth and fifth class social science teachers about values education applications. (Unpublished Master Thesis), Hacettepe Üniversitesi, Social Sciences Institute, Ankara. Turkey. 
Çetinkaya, B. (2010). Pre-school Education in Turkey and Problems. (Unpublished Master Thesis) Beykent University, İstanbul, Turkey.

Cevizci, A. (1997). The Philosophy Dictionary, (Expanded second edition) İzmir: Ekin Publishing.

Denzin, N. K., \& Lincoln, Y. S. (2000) (Second edition). Handbook of Qualitative Research. London: Sage.

Deveci, H., \& Selanik, A. T. (2009). Values In Daily Life According To Diaries Of Primary School Students. The Journal of International Social Research, 2(6), 167-181. Retrieved from http://www.sosyalarastirmalar.com/cilt2/sayi6pdf/deveci_ay.pdf

Dirican, R., \& Dağlıŏlu, H. E. (2014) Analyzing Some Basic Values in Illustrated Story Books for 3-6 Years Old Children. Cumhuriyet International Journal of Education-CIJE , 3(2), 44-69.

Geisel, T. S. (1940). Horton Hatches the Egg. New York, U.S.A.: Random House

Glaser, B. G., \& Strauss, A. L. (1967). The discovery of Grounded Theory: Strategies for Qualitative Research. Chicago: Aldine Publishing Company

Gömleksiz, M. N., \& Cüro, E. (2011). An Assessment of students' attitudes towards values in Social Studies curriculum. Journal of Human Sciences, 8(1), 95-134.

Gönen, M., Katranc1, M., Uygun, M., \& Uçuş, Ş. (2011). A Study of Primary School Students' Children's Books Related to Physical Structures, Content and Illustrations. Education and Science, 36(160), 250-265

Halstead, J. M., \& Taylor, M. J. (2000). Learning and teaching about values: A review of recent research. Cambridge Journal of Education, 30(2), 169-202. https://doi.org/10.1080/713657146

M.E.B. ( Ministry of National Education) (2014) http://mevzuat.meb.gov.tr/html/25486_html

Miles, M. B., \& Huberman, A. M. (1994). An expanded sourcebook qualitative data analysis. (Second Edition). California: Sage Publications, Inc.

Neuman, W. L. (2012). Social Research Methods: Quantitative and Qualitative Approaches I-II. Volume. (Fifth edition). İstanbul: Publishing Room.

Özyurt, Ö. (2014). Fairies Tell Us About Responsibility. Ankara: 1001 Çiçek Books Publisher.

Pehlivan, İ. (2003) Managerial, Professional and Organizational Ethics.Ankara: Pegem A Yayınc1lik .

Pring, R. (2010). International Research Handbook on Values Education and Student Wellbeing In. T. Lovat, R. Toomey \& N. Clement (Ed.). Preface. (v-vi) UK: Springer. https://doi.org/10.1007/978-90-481-8675-4

Qualitative Research Method (2016 a). Retrieved from (http://libguides.usc.edu/writingguide/qualitative).

Qualitative Research Method (2016 b). Retrieved from https://web.csulb.edu/ msaintg/ppa696/696quali.htm).

Ruffin, N. J. (2009). Developing Responsibility And Self-Management In Young Children: Goals of Positive Behavior Management Retrieved from http://www.pubs.ext.vt.edu/350/350-052/350-052.html

Rush, K., \& Lipski, K. (2009). Teaching social skills through children's literature. Illinois Reading Council Journal, 37(4), 20-25 (delisted)

SLOs, Bloom's Taxonomy, Cognitive, Psychomotor, and Affective Domains. Retrieved from http://www.craftonhills.edu/ /media/Files/SBCCD/CHC/Faculty\%20and\%20Staff/SLOs/Step\%201/Blooms\%20Ta xonomy\%20and\%203\%20Domains\%20of\%20Learning.pdf

Stranix, E., \& Fleishman, M. (1979). The "Eggs-act" Way to Teach Responsibility. Teacher, 96(9), May-Jun. 44-45. ERIC Number: EJ218944. Retrieved from https://eric.ed.gov/?q=The+eggs+act+

Strauss, A., \& Corbin, J. (1990). Basics of Qualitative Research: Grounded Theory Procedures and Techniques. Newbury Park, C. A.: Sage.

Such, E., \& Walker, R. (2004). Being Responsible and Responsible Beings: Children's Understanding of Responsibility, Children \& Society, 18(3), 231-242.

Tay, B., Durmaz, F., \& Şanal, M. (2013). Views of Students about Value and Values Education within the Scope of Social Studies Course Gazi University Gazi Journal of Education Faculty, 33(1), 67-93. Retrieved from http://gefad.gazi.edu.tr/article/viewFile/5000078381/5000072604

TDK (Turkish Language Association) (2014). Ankara, Great Turkish Dictionaray.

Tepecik, B. (2008). The Teacher's Opinions about acquiring the value of responsibility in social studies course. (Unpublished Master Thesis.) Anadolu Universty, Institute of Educational Sciences, Eskişehir, Turkey. 
Tozlu, N. (1992). Thoughts on Our Education Problems. Van, Van Yüzüncü Yıl University Publishing.

Varış, F. (1998). Curriculum Development in Education “Theory and Techniques” İstanbul: Alkım Yayınevi.

Yaşar, Ş., \& Çengelci, T. (2012). A Case Study Regarding Values Education in Social Studies Course. International Journal of Eurasia Social Sciences, 3(9). Retrieved from http://www.ijoess.com/Makaleler/591816596_SYasar\&TCengelci.pdf

Yavuzer, H. (1998). Child Education Handbook. Istanbul: Remzi Publishing House.

Yeşil, R. (2003). The Impact of the School and the Family on the Development of Awareness of Responsibility. Eurasian Journal of Education Research. 10. 175-183. Retrieved from http://ejer.com.tr/tr/index.php?git=22\&kategori=41\&makale=512

Yiğittir, S. (2010). Values That Parents of the Primary Pupils Demand to be Educated in School, Journal of Values Education, 8(19), 207-223. Retrieved from http://www.okuloncesi.net/upload/dosyalar/20111113/2306/ded19mak7.pdf

Yıldırım, A., \& Şimşek, H. (2006). Qualitative research methods in the social sciences. Ankara: Seçkin Publication.

\section{Copyrights}

Copyright for this article is retained by the author(s), with first publication rights granted to the journal.

This is an open-access article distributed under the terms and conditions of the Creative Commons Attribution license which permits unrestricted use, distribution, and reproduction in any medium, provided the original work is properly cited. 